\title{
DO THE GOVERNMENT EXPENDITURE AUDITS CORRELATE WITH CORRUPTION IN THE PUBLIC PROCUREMENT?
}

\author{
Deri Yanto ${ }^{1}$, Vid Adrison ${ }^{2}$ \\ Badan Pemeriksa Keuangan Republik Indonesia, Indonesia ${ }^{1}$ \\ Faculty of Economics and Business, University of Indonesia, Indonesia ${ }^{2}$ \\ deri.yanto@bpk.go.id ${ }^{1}$ \\ vadrison@gmail.com²
}

\begin{abstract}
Public procurement is the main area of corruption in the government. This study aims to examine the correlation between government expenditure audit conducted by BPK and local government corruption behavior. This study uses a fixed effect panel regression approach and the dependent variable is the value of irregularities in the public procurement sector in all local governments in Indonesia. This study found that the government expenditure audit carried out in the previous period correlated with changes in local government corruption behavior. Local governments will reduce corruption behavior as an implication of changing views and calculating expected cost corruption based on their experience of being audited. Besides, local governments expect their probabilities to be re-audited. It is evident in the local government which has not been audited for three years that it will try to reduce its corrupt behavior because it is expected that this year will be audited again. This study suggests an increase in audit frequency that is expected to decrease the aggregate corruption level in public procurement in local government.
\end{abstract}

\section{KEYWORDS:}

Audit; corruption; expenditure; local government

\section{ARTICLE HISTORY:}




\section{INTRODUCTION}

Corruption is one of the main problems in developing countries. Corruption causes additional costs that must be incurred by the government in providing public services. Corruption results in inefficiencies in government spending. It even results in the low economic growth of a country (Olken, 2007). Public procurement is the main area of corruption in the government. The large portion of the value of public procurement to the government budget is directly proportional to the potential for corruption in this sector. The potential vulnerability to corruption in public procurement, in addition to the tremendous value of financial transactions involved, is also due to the high complexity of the public procurement and the intense interaction between government and business circles (OECD, 2013).

Corruption in the government is defined as the activity of public officials in taking personal advantage of transactions involving the government and third parties illegally in the form of financial or indirect benefits (RoseAckerman, 1975; Shleifer \& Vishny, 1993). Based on the theory of the economics of crime developed by Becker (1968), this study views corruption as a form of violation committed by individuals/groups for their interests. Corruption actions are carried out because the expected benefits received are greater than the costs and income obtained legally.

In public procurement corruption, perpetrators expect great benefits. Public procurement is an area that involves large financial value. The process of procuring service goods is also very complex and involves many parties (Ferwerda, Deleanu, \& Unger, 2016; KPK, 2015; OECD, 2013). Therefore, if the local government has a large budget for public procurement, the greater the benefits expected to be received from corruption.
Within the theoretical framework, the government expenditure audit is one of the costs that corruption actors consider. The individual audit experience provides a new perspective for the perpetrators in their corruption activities. It drives them to reduce corruption activities because audits can reveal illegal activities. Otherwise, they seek other ways so that illegal activities cannot be detected by audits (Kleven, Knudsen, Kreiner, Pedersen, \& Saez, 2011). Conversely, the level of capital expenditure represents the level of expected benefits that can be obtained by perpetrators of corruption in a local government. The higher the value of capital expenditure, the higher the opportunity to commit corruption, so that the benefits that can be obtained are even more significant.

Data from The Audit Board of The Republic of Indonesia (BPK) in 2014-2017 also showed that corruption in public procurement was very dominant. During this time, irregularities were uncovered in all local governments in Indonesia, with a value of 6,947 billion rupiah in state losses. Four thousand one hundred forty-one $(4,141)$ billion, or $60 \%$ is a deviation that occurs in the service procurement sector (BPK RI, 2018). Nevertheless, such corruption is difficult to detect and measure, so there is no general agreement on the best alternative in efforts to eradicate corruption. One of the efforts to eradicate corruption is to determine the right combination of enforcement efforts and punishment levels (Becker \& Stigler, 1974). One of the law enforcement efforts is an audit of state financial management (Avis, Ferraz, \& Finan, 2018).

BPK is an institution that has the authority to conduct audits of the management of state finances carried out by the government, both the central and local governments. The type of audit that is routinely carried out in addition to financial statements audit is a special- 
purpose audit on government expenditure (called government expenditure audit). Government expenditure audits focus on efforts to detect deviations by the government in carrying out expenditures under state/local government budget (Anggaran Pendapatan dan Belanja Negara, APBN/Anggaran Pendapatan dan Belanja Daerah, APBD) for the benefit of the people.

In a series of monitoring of state financial accountability, BPK has the authority to audit the management and accountability of state finances. All central, local, governmentowned, or private agencies, if they manage the state finances, are the object of the audit. Given BPK's high authority in conducting audits, it can play a role in efforts to eradicate corruption through efforts to detect and investigate irregularities (BPK RI, 2015c). In the financial statement audit, it does not merely an audit of assertions in the financial statements. The audit also determines the existence of irregularities in the management of state finances. Thus, the results of the financial statement audit are not only opinions but reports of non-compliance with laws and regulations, including irregularities that are detrimental to state finances.

BPK plays a broader role in efforts to detect irregularities in local government spending through government expenditure audits and investigative audits. A series of government expenditure audits were conducted to test the validity and compliance of the implementation of local government spending. The report on the government expenditure audit cannot indeed be directly used as a basis for fraud convictions. It provides initial information on the disclosure of fraud acts of corruption, especially in public procurement. The information available in the government expenditure audit report includes the value of the financial loss of the state and the responsible party. To be used in legal prosecution, the government expenditure audit re- port is submitted to law enforcement officials and/or followed up with an investigation and calculation of state losses audits also carried out by BPK.

The investigative audit aims to provide legal construction of the disclosures revealed and facilitates law enforcement in the prosecution process. In 2016, BPK formed an echelon 1 working unit that has unit-specific tasked conducting investigative audits and calculating state losses. The establishment of the working unit aims to further enhance the role of the institution in eradicating corruption. In 2017, this unit has conducted only 4 investigative audits and 22 state loss calculations for local governments with a total corruption value of 449.2 billion rupiah (BPK RI, 2018). Compared to government expenditure audit and government financial audit, the number of the investigative audits were only a few (4 audits compared to 98 and 542 audits in 2017).

Research on the relationship of the audit with the level of corruption itself has not produced an understanding of consensus. Avis et al. (2018) and Olken (2007) concluded that audits affected future local government corruption decisions. Bobonis, Fuertes, and Schwabe (2016), in their research, found that the audit impact on the level of corruption only occurred in the short term. Khan (2006b) and Porter (1993) do not see the effect of audits on the level of corruption. Liu and Lin (2012) also Rosyadi and Budding (2017) even found the opposite; auditing increased detected corruption. Indeed, both studies have different emphases.

Rosyadi and Budding (2017) focus on the effectiveness of performance of the Indonesian Finance and Development Supervisory Agency, known as Badan Pengawasan Keuangan dan Pembangunan (BPKP) as the internal auditor while Liu and Lin (2012) examine the interactions among audit detec- 
tion, audit rectification and bureaucratic corruption at the local level in China.

Olken (2007) researched the impact of audits on the level of corruption in infrastructure projects in villages in Indonesia. In his research, it was concluded that the audit was negatively correlated to the value of corruption. However, this research has not been able to conclude the correlation of audits by the government with the level of corruption in public procurement. It is because the audit is not conducted by an external auditor, but by an internal auditor, and it will affect the post-audit process if irregularities are found. Besides, the context of the government expenditures is not through the public procurement mechanism, but it is carried out in a self-managed mechanism (swakelola), this results in different corrupt behaviors. The level of observation carried out by Olken is the village/urban village (kelurahan), which receives grant funds through the Kecamatan Development Project (KDP) program from the World Bank. This level observation is difficult to generalize the level of local government because there are differences in the complexity of the bureaucracy.

Based on previous literature and research that has been conducted mainly in Indonesia, there is a research gap to be further investigated especially the correlation of government audits with the level of corruption in public procurement. This study aims to identify the correlation between government expenditure audits conducted by the BPK against the level of corruption in public procurement for all local governments in Indonesia. This study analyzes the irregularities in the public procurement valued at 4,141 billion rupiah disclosed by the BPK during the 2014-2017 period.

\section{RESEARCH METHOD}

This study analyzes panel data sourced from the Summary of Semester Audit Result (Ikhtisar Hasil Pemeriksaan Semester, IHPS) issued by the BPK in 2014 until 2017. The dependent variable in this study is the value of irregularities in public procurement of all local governments in Indonesia for the period 2014 to 2017. In the IHPS, all irregularities revealed have been classified according to its impact, whether it is detrimental to the government's finances or not. Irregularities in public procurement used as a proxy for corruption in public procurement, especially irregularities in public procurement, causing state finances losses.

The weakness of the classification of irregularities in the IHPS is that there is no information about the perpetrators of irregularities. So it cannot be identified whether government officials, partners, or both committed it. However, because partners work with appointed and on behalf of local governments, irregularities occur in the name of local governments (both as local government officials and local government partners or both). In several previous studies, corruption was not separated from officials or partners (Avis et al., 2018; Ferraz \& Finan, 2011; Olken, 2007).

The use of irregularities data from audit results as a proxy for corruption had been used in several previous studies. Avis et al. (2018); Bobonis et al. (2016); Brollo, Nannicini, Perotti, and Tabellini (2013); also Ferraz and Finan (2011) used the audit results of the central government as a proxy for corruption in all local governments in Brazil. Olken (2007) uses the results of physical audit work as a proxy for corruption in infrastructure improvement programs in villages in Indonesia. Previous studies used the Corruption Perception Index as a proxy for corruption in local governments in Indonesia 
(Masyitoh, Wardhani, \& Setyaningrum, 2015). However, the use of the Corruption Perception Index has a weakness. Corruption Perception Index is not available in all local governments. Also, the Corruption Perception Index survey is not carried out every year, so it is difficult to use the data on a panel basis between local governments.

Some researchers used the Corruption Eradication Commission's (Komisi Pemberantasan Korupsi, KPK) data as a proxy for corruption in local governments in Indonesia (Citra, 2018). The authors did not use the KPK data due to no access to and completeness of the data. Because corruption in the public procurement's data is not normally distributed, authors transformed it into logs. However, corruption in the public procurement's data also contains several zero values, so before the value of corruption is transformed into logs, the data were individually added. The authors used this strategy to ensure that data after transformation did not contain the missing value (cannot be processed).

The first independent variable is a government expenditure audit. This variable is made in the form of a variable dummy. If the BPK had audited a local government in the previous period, it is 1 . Otherwise, it is zero. Because the purpose of the study is to find out future corruption behavior after an audit, the variable government expenditure audit must have happened (lag time), or government expenditure has been audited in the previous year. This variable is used to capture audit correlations with future local government corruption decisions. The experience by the audited local government will provide a different view of the audit results. For example, how can audits detect irregularities and their impact on losses that must be borne and the reputation that will be disrupted (Avis et al., 2018). On this matter, the local government will update the expected cost of corruption based on audited experience (Avis et al., 2018; Kleven et al., 2011). This variable also becomes the primary variable following the theoretical framework that has been described previously.

The time-lag of government expenditure audit variables are made until lag time 3 provides a more comprehensive picture of audit correlations with the value of corruption. The audit report is submitted in the middle of the following year. At that time, the procurement process for the following year had reached the stage of determining the winner/ starting the work. Also, the budget planning process for two years from the current year has begun, so that a minimum of 2 years lag time is required. While the 3 -year lag time is used to capture whether audit correlations with irregularities occur consistently or only correlate in the short term.

Furthermore, the government expenditure audit variable above interacted with the value of corruption in the public procurement that was disclosed in the government expenditure audit. Interaction with the value of corruption that was revealed aims to determine the correlation of the magnitude of the value of corruption that succeeded in the previous period's audit of total corruption in the current year. Do the local governments that have committed corruption to have different corruption behavior in the future compared to clean local governments? Based on the value of corruption revealed, it does not make any difference to the local government corruption behavior.

In addition to the main explanatory variables above, this study also includes control variables to capture the effect of variables other than the main explanatory variables. The first control variable is capital expenditure, both in nominal terms as a dummy ratio of capital expenditure to total expenditure. These two variables are to capture the ex- 
pected benefits from the local government. The higher the value of local government capital expenditure, the higher the expected benefit of corruption. The capital expenditure variable is transformed into logs to ensure that data is normally distributed and easy to interpret.

The next control variable is the Gross Regional Domestic Product (GRDP) per capita. This variable is used as a proxy for corruptor's legal income. Legal income, per the theoretical framework, is the opportunity cost when perpetrators decide to commit acts of corruption. The higher the legal income of the perpetrators, the lower perpetrators will commit corruption. Perpetrators will look for areas of corruption that provide benefits that are far higher than the legal income that has been obtained so far. In this study, the salaries of civil servants are not used as legal revenue proxies because corruption perpetrators of procurement of goods can be bureaucracy or private parties or both. The value of GRDP per capita is transformed into logs to make sure data is normally distributed and easy to interpret.

This study uses a regression quantitative analysis method to answer the research question that the audit has a correlation with the level of corruption in public procurement. The basic equation model, Corruption $=\mathrm{f}$ (Audit, $\mathrm{X}$ ), describes the value of corruption in the public procurement of the local government of $\mathrm{i}$ region in the fiscal year. While $t$ is a function of the government expenditure audit (Audit) $i$ in the fiscal year $t$ and control variables (X). Based on the basic model, a regression model is prepared as follow:

$$
\begin{aligned}
C= & \beta_{0}+\beta_{1} \text { audit }_{i t-1}+\beta_{2} \text { audit }_{i t-2}+\beta_{3} \text { audit }_{i t-3}+\beta_{4} \text { audit } x \\
& \text { corruptionrevealed }_{\mathrm{it}-1}+\beta_{5} \text { audit } x \text { corruptionre- } \\
& \text { vealed }_{\mathrm{it}-2}+\beta_{6} \text { audit } x \text { corruption revealed }_{\mathrm{it}-3}+\mathrm{x}_{\mathrm{it}}+\delta_{\mathrm{t}} \\
& +\mathrm{u}_{\mathrm{it}}
\end{aligned}
$$

Where $\mathrm{C}$ is the value of corruption in the public procurement in local government $i$ in period $\mathrm{t}$ (in log-based). ( $\beta_{1}$ audit $_{\mathrm{it}-1}+\beta_{2}$ audit $_{\text {it- }}$ ${ }_{2}+\beta_{3}$ auditit-3 $_{\text {it }}$ ) is the dummy BPK conducting an audit of expenditure in local government $i$ in period $t$ with value 1 done audited and value $o$ are not audited. The interaction variable audit it with the value of corruption (audit $\mathrm{x}$ corruption revealed it) is knowing the correlation of the value of corruption revealed from the audit of the total value of corruption. The variable $x_{i t}$ is a vector of control variables represented by a capital expenditure log, dummy high capital expenditure ratio, and GRDP per capita area $i$ period $t$. Do not forget to include the year effect $\delta_{t}$ to issue the effect of trends due to changes in the year in each region.

Several tests were carried out to find out the validity of the data and the selection of the best models. The authors used OLS regression in this model because dependent variable data is normally distributed. To find out which model is most suitable, whether the fixed effect or random-effect model, the authors used the Hausman test. Whereas for data validity, authors used a multicollinearity test. The robust standard error is used to minimize the problem of heteroscedasticity. The authors also performed robustness checks via stepwise regression and normalized dependent variable value (corruption in the public procurement) by dividing capital expenditure value.

\section{RESULT AND DISCUSSION}

The data used came from 439 local governments in Indonesia during the 2014-2017 period with a total of 2.156 observations that were made except data from three local governments (Muna, Central Buton, and South Buton) which were incomplete from 2014. The descriptive statistic of the data presented in Table 1. The average total corruption in the public procurement in each local go- 
Table 1. Descriptive Statistics

\begin{tabular}{lccccc}
\hline \multicolumn{1}{c}{ Variable } & Unit & Mean & Std.Dev & Min & Max \\
\hline Corruption in the Public Procurement & Bil. Rupiah & 2,16 & 7,04 & 0 & 261,00 \\
\hline Audit (lag time 1 year) & Dummy & 0,26 & 0,44 & 0 & 1 \\
\hline Audit (lag time 2 year) & Dummy & 0,28 & 0,45 & 0 & 1 \\
\hline Audit (lag time 3 year) & Dummy & 0,27 & 0,45 & 0 & 1 \\
\hline Audit x corruption revealed (lag time 1 year) & Bil. Rupiah & 0,36 & 1,51 & 0 & 43,82 \\
\hline Audit x corruption revealed (lag time 2 year) & Bil. Rupiah & 0,49 & 2,34 & 0 & 81,39 \\
\hline Audit x corruption revealed (lag time 3 year) & Bil. Rupiah & 0,48 & 2,42 & 0 & 81,38 \\
\hline Capital expenditure & Bil. Rupiah & 384,00 & 5,46 & 26,80 & 11.000 \\
\hline High ratio capital expenditure & Dummy & 0,41 & 0,49 & 0 & 1 \\
\hline GRDP per capita & Mil. Rupiah & 3,46 & 3,51 & 0,86 & 37,10 \\
\hline
\end{tabular}

vernment is 2.16 billion rupiah. Then, the average value of capital expenditure for each local government is 384 billion rupiah per budget year. So that it can be calculated that the share of corruption value revealed to the value of capital expenditure is 0.7 percent. The average value of irregularities from government expenditure audit reports per local government is smaller than that of financial statements. It is because the expenditure audit is not carried out every year as well as financial report audits. Further information, the average local government income per capita is 3,46 million rupiah per month, the lowest is 860 thousand rupiah, and the highest is 37,1 million rupiah.

Furthermore, upon observation of corruption value distribution per capital expenditure aggregate on each province, as listed in Figure 1. Corruption value is relatively high in the provinces in Central Sumatra and eastern Indonesia. While Java and Kaliman-

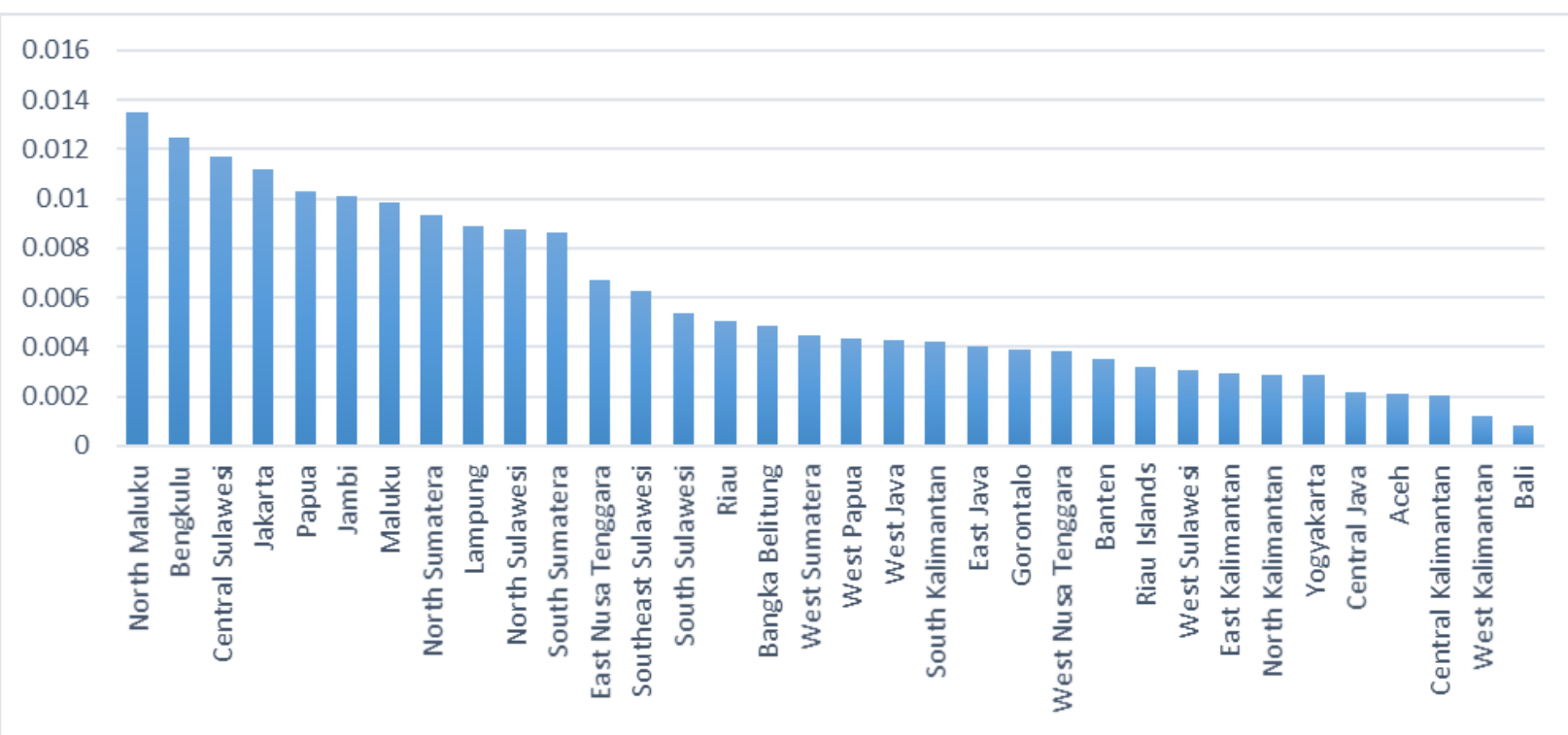

Figure 1. Province's Aggregate Corruption Value per Capital Expenditure in 2014-2017

Source: BPK RI (2018), processed 
tan provinces are the regions with low corruption value per capital expenditure.

In the 2014-2017 period, BPK conducted 528 government expenditure audits. In that period, the trend of government expenditure audits tended to decline. In 2014 there were 134 audits, 2015 increased to 160 audits, and in 2016 and 2017, they continued to decline, 137 times and 98 times, respectively. The government expenditure audit in 2017 was less than in previous years because, in that year, BPK conducted two thematic audits. The two thematic audits were conducted by BPK Representative Office in all provinces. BPK usually conducted one thematic audit each year. Whereas in 2015, government expenditure audits were more frequently because, in that year, there was a thematic audit of infrastructure capital expenditure, so that the audit portion of expenditure increased.

Based on the two-way scatterplot analysis, as presented in Appendix 1, it can be seen that the relationship between the values of corruption in public procurement with government expenditure audit lag one year is positive. Likewise, the relationship between the values of corruption in public procurement with the government expenditure audit conducted two years earlier is also positive. Whereas, if the audit is conducted three years earlier, there is a negative relationship with the value of corruption. To obtain a more comprehensive conclusion to answer the research questions, an empirical test was carried out in the next discussion.

The empirical test begins by estimating several model specifications, as listed in Table 1. Model 1 is the basic model, which only includes dummy audit variables. Model 2 adds interaction audit variables with the value of corruption revealed. Whereas models 3 and 4 are models that have been added with control variables and year effects. It is used to test the consistency of the results of interest variables. All of the models use fixed effects and are consistent with the results of the Haussman test which concluded that the fixed effect model is the best in this study (Appendix 2).

Based on the estimation results in columns 1 to 4 of table 1 , it can be seen that the government expenditure audit carried out in the previous year negatively correlated with the value of corruption in the public procurement of the local governments. These results are consistent with the initial conjecture and the results of several previous studies (Avis et al., 2018; Bobonis et al., 2016; Di Tella \& Schargrodsky, 2003; Olken, 2007). It proves that the audit provides a newer view of the expected cost of the local government for corruption.

Government expenditure audits in local governments will result in broader coverage of audited government expenditures compared to local governments that are not audited. It has the potential to increase the value of corruption that can be detected. In line with the research conducted by Kleven et al. (2011), audits conducted in the previous period correlated with changes in the views of individuals/groups in the decision to act illegally. An audit provides a deterrent effect on individuals. The deterrent effect is derived from financial losses that must be incurred, penalties, even for heads of local government, potentially affecting electability for the next period of elections (Avis et al., 2018; Ferraz \& Finan, 2011). Understandably, if the expenditure was audited in the previous period, the local government would reduce corruption in the next period.

However, in the following period, it turned out that the corruption behavior of the local government had returned to normal. So local governments, that have been audited two years before, and have not been audited, are 
not different in their behaviors. The interesting is the result of the next variable, namely the audit lag variable 3 . It turned out that the local governments that were audited three years earlier tended to be less corrupt than those who were not audited. This condition shows that there is an attempt by the local government to guess their probability of audit. When the local government has not been audited for two years, they will return to their previous behavior. However, when they have not been audited for three years, the local government will aware and try to reduce corruption. It is because they expect that this year they will be audited as three years before.

Furthermore, the previous audit interaction variable with the value of corruption revealed did not correlate with the value of public procurement corruption in the current year. It shows that the variation in the value of corruption revealed to the government expenditure audit in the previous period does not correlate with the value of corruption in public procurement. It indicates that despite the relatively small value that can be detected in the government expenditure audit, it has correlated similarly with the local government with more significant corruption. So, the established correlation is not solely because of the detectable value of corruption. But the audit process itself provides a negative correlation to the future corruption behavior of the local government.

The capital expenditure variable results show a positive and significant correlation. This result shows that the increase in capital expenditure has resulted in an expected benefit change that can correlate with changes in the corruption behavior of local governments. Increased capital expenditures in nominal, will increase the expected benefits of local governments to commit capital expenditure corruption. These incentives come from the increasing value of the budget which increases the value and amount of procurement of goods and services. When capital expenditure increases by 1 percent in nominal terms, it will increase the value of corruption in the procurement of goods by 1.15 percent at a significance of 99 percent. It is consistent with several previous studies which concluded that the level of capital expenditure positively correlated with the level of corruption (Goel \& Nelson, 1998; Hopkin \& Pose, 2007; Khan, 2006a).

While the GRDP per capita variable does not significantly correlate with the value of corruption, it shows that the benefit from the corruption of public procurement remains higher than income per capita. So for any changes in income per capita during the 2014-2017 period did not correlate with corruption in the public procurement in local governments.

To get a consistent estimation in describing conditions, authors carry out robustness checks. Authors were providing an alternative measurement of the value of corruption. In the primary model, the value of corruption is the value of detected corruption. As an alternative measurement, authors normalized this value by the capital expenditure realization value. These alternative measurements follow the measurements made by Ferraz and Finan in 2011 also Zamboni and Litschig in 2018. The results of the robustness check are presented in Appendix 4.

The estimation results for the robustness check show that estimates are consistent with the primary model in Appendix 3. Despite public procurement corruption value has been normalized with the value of capital expenditure, the estimation results still show that the government expenditure audit variable of the previous period and the previous three years correlated with the value of corruption in public procurement while the interaction of audit variables with the revealed 
value of corruption does not correlate with the value of corruption.

\section{CONCLUSION}

This study shows that the government expenditure audit carried out in the previous period correlated with changes in local government corruption behavior. The local government will try to reduce its corrupt behavior as an implication of changing views/ calculating the expected cost of future corruption actions. Besides, local governments expect their probabilities to be audited again. It is evident in local governments that have not been audited for three years will try to reduce their corruption actions because they expect to be audited this year. Although government expenditure audits provide a negative correlation to future corruption behavior. The addition of capital expenditure correlates with the increase in the value of corruption. It can be understood because the expected benefit from additional capital expenditure will also increase.

Based on this, the BPK needs to consider the increasing number of audits in detecting irregularities. We hope more government expenditure audits conducted by BPK can increase the expected cost of corruption for potential corruption perpetrators. So, it will decrease the aggregate corruption level in public procurement in local government. Also, to respond to changes in corruption behavior due to variations in capital expenditure, BPK needs to add capital expenditure value variables in determining the audit sample.

The limitation of this study is the use of data from cases of irregularities in the public procurement presented in IHPS published by BPK. The data has not fully captured the condition of the actual value of public procurement corruption throughout Indonesia. For this reason, further research is needed by using data compilation of public procurement corruption from BPK, KPK, and other law enforcement agencies to obtain a more comprehensive picture. Besides, other factors need to be correlated with corruption, both the characteristics of local government and the factors in the audit institution itself, for example, the characteristics of auditors who conduct audits.

\section{REFERENCES}

Avis, E., Ferraz, C., \& Finan, F. (2018). Do government audits reduce corruption? Estimating the impacts of exposing corrupt politicians. Journal of Political Economy, 126(5), 19121964. doi: 10.1086/699209

Becker, G. S. (1968). Crime and punishment: An economic approach. Journal of Political Economy, 76(2), 169-217. doi: 10.1086/259394

Becker, G. S., \& Stigler, G. J. (1974). Law enforcement, malfeasance, and compensation of enforcers. The Journal of Legal Studies, 3(1), 1-18.

Bobonis, G. J., Fuertes, C. L. R., \& Schwabe, R. (2016). Monitoring corruptible politicians. American Economic Review, 106(8), 2371-2405. doi: 10.1257/aer.20130874

BPK RI. (2014a). Ikhtisar Hasil Pemeriksaan Semester (IHPS) I Tahun 2014 (Summary of Semester Audit Results I Year 2014). Retrieved from https:// www.bpk.go.id/ihps

BPK RI. (2014b). Ikhtisar Hasil Pemeriksaan Semester (IHPS) II Tahun 2014 (Summary of Semester Audit Results II Year 2014). Retrieved from https://www.bpk.go.id/ihps

BPK RI. (2015a). Ikhtisar Hasil Pemeriksaan Semester (IHPS) I Tahun 2015 (Summary of Semester Audit Results I Year 2015). Retrieved from https:// www.bpk.go.id/ihps

BPK RI. (2015b). Ikhtisar Hasil Pemeriksaan Semester (IHPS) II Tahun 2015 (Summary of Semester Audit Results 
II Year 2015). Retrieved from https:// www.bpk.go.id/ihps

BPK RI. (2015c). Keputusan Badan Pemeriksa Keuangan Nomor 7 Tahun 2015 tentang Rencana Strategis Badan Pemeriksa Keuangan Tahun Anggaran 2016-2020 (BPK's Decree Number 7 Year 2015 concerning BPK's Strategic Plan for Year 20162020). Retrieved from https:// www.bpk.go.id/assets/files/ attachments/

attach_post_1457317017.pdf

BPK RI. (2016a). Ikhtisar Hasil Pemeriksaan Semester (IHPS) I Tahun 2016 (Summary of Semester Audit Results I Year 2016). Retrieved from https:// www.bpk.go.id/ihps

BPK RI. (2016b). Ikhtisar Hasil Pemeriksaan Semester (IHPS) II Tahun 2016 (Summary of Semester Audit Results II Year 2016). Retrieved from https://www.bpk.go.id/ihps

BPK RI. (2017a). Ikhtisar Hasil Pemeriksaan Semester (IHPS) I Tahun 2017 (Summary of Semester Audit Results I Year 2017). Retrieved from https:// www.bpk.go.id/ihps

BPK RI. (2017b). Ikhtisar Hasil Pemeriksaan Semester (IHPS) II Tahun 2017 (Summary of Semester Audit Results II Year 2017). Retrieved from https:// www.bpk.go.id/ihps

BPK RI. (2018). Ikhtisar Hasil Pemeriksaan Semester (IHPS) I Tahun 2018 (Summary of Semester Audit Results I Year 2018). Retrieved from https:// www.bpk.go.id/ihps

Brollo, F., Nannicini, T., Perotti, R., \& Tabellini, G. (2013). The political resource curse. American Economic Review, 103(5), 1759-1796. doi: 10.1257/ aer.103.5.1759

Citra, A. (2018). The effect e-procurement to corruption in the public procurement. (Unpublished master's thesis).

Di Tella, R., \& Schargrodsky, E. (2003). The role of wages and auditing during a crackdown on corruption in the city of Buenos Aires. The Jourmal of Law \& Economics, 46(1), 269-292. doi: $10.1086 / 345578$

Ferraz, C., \& Finan, F. (2011). Electoral accountability and corruption: Evi- dence from the audits of local governments. American Economic Review, 101(4), 1274-1311. doi: 10.1257/ aer.101.4.1274

Ferwerda, J., Deleanu, I., \& Unger, B. (2016). Corruption in public procurement: Finding the right indicators. European Journal on Criminal Policy and Research, 23, 245-267. doi: 10.1007/s10610-016-9312-3

Goel, R. K., \& Nelson, M. A. (1998). Corruption and government size: A disaggregated analysis. Public Choice, 97, 107-120. doi: 10.1023/ A:1004900603583

Hopkin, J., \& Pose, R. (2007). "Grabbing hand" or "helping hand"?: Corruption and the economic role of the state. Governance, 20(2). 187-208. doi: 10.1111/j.1468-0491.2007.00353.x

Khan, M. H. (2006a). Determinants of corruption in developing countries: the limits of conventional economic analysis. In S. Rose-Ackerman (Ed.), International Handbook on the Economics of Corruption (pp.216-245). doi: 10.4337/9781847203106.00015

Khan, M. H. (2006b). Governance and anticorruption reforms in developing countries: policies, evidence, and ways forward (G-24 Discussion Paper Series). Retrieved from United Nations Conference On Trade and Development website: https:// unctad.org/en/docs/ gdsmdpbg2420064_en.pdf

Kleven, H. J., Knudsen, M. B., Kreiner, C. T., Pedersen, S., \& Saez, E. (2011). Unwilling or unable to cheat? Evidence from a randomized tax audit experiment in Denmark. Econometrica Journal of Econometric Society, 79 (3), 651-692. doi: 10.3982/ECTA9113

KPK. (2015). Laporan Hasil Kajian Pencegahan Korupsi Pada Pengadaan Barang dan Jasa Pemerintah. Retrieved from https://acch.kpk.go.id/id/berkas/ litbang/kajian-pencegahan-korupsipada-pengadaan-barang-dan-jasapemerintah

Liu, J., \& Lin, B. (2012). Government auditing and corruption control: Evidence from China's provincial panel data. China Journal of Accounting Research, 5(2), 163-186. doi: 10.1016/ 
j.cjar.2012.01.002

Masyitoh, R. D., Wardhani, R., \& Setyaningrum, D. (2015, June). The influence of audit opinion, audit findings, and follow-up of audit results on corruption perception in second level local government. Paper presented at the 18th National Symposium on Accounting at North Sumatera University.

OECD. (2013). Preventing corruption in public procurement. Retrieved from http://www.oecd.org/gov/ethics/

Corruption-Public-ProcurementBrochure.pdf

Olken, B. A. (2007). Monitoring corruption: Evidence from a field experiment in Indonesia. Journal of Political Economy, 115(2), 200-249. doi: 10.1086/517935

Porter, B. (1993). An empirical study of the audit expectation-performance gap. Accounting and Business Research,
24(93), $\quad$ 49-68. 10.1080/00014788.1993.9729463

Rose-Ackerman, S. (1975). The economics of corruption. Journal of Public Economics, 4(2), 187-203. doi: 10.1016/0047-2727(75)90017-1

Rosyadi, C. F., \& Budding, T. (2017). The effectiveness of BPKP fraud audit finding on determining the level of corruption in Indonesian provinces. Journal of Society and Governance, 1 (2), 88-109.

Shleifer, A., \& Vishny, R. W. (1993). Corruption. The Quarterly Journal of Economics, 108(3), 599-617.

Zamboni, Y., \& Litschig, S. (2018). Audit risk and rent extraction: Evidence from a randomized evaluation in Brazil. Journal of Development Economics, 134, 133-149. doi: 10.1016/ j.jdeveco.2018.03.008

\section{APPENDICES}

Appendix 1. Scatter Plot Value Of Corruption In The Public Procurement And Government Audit

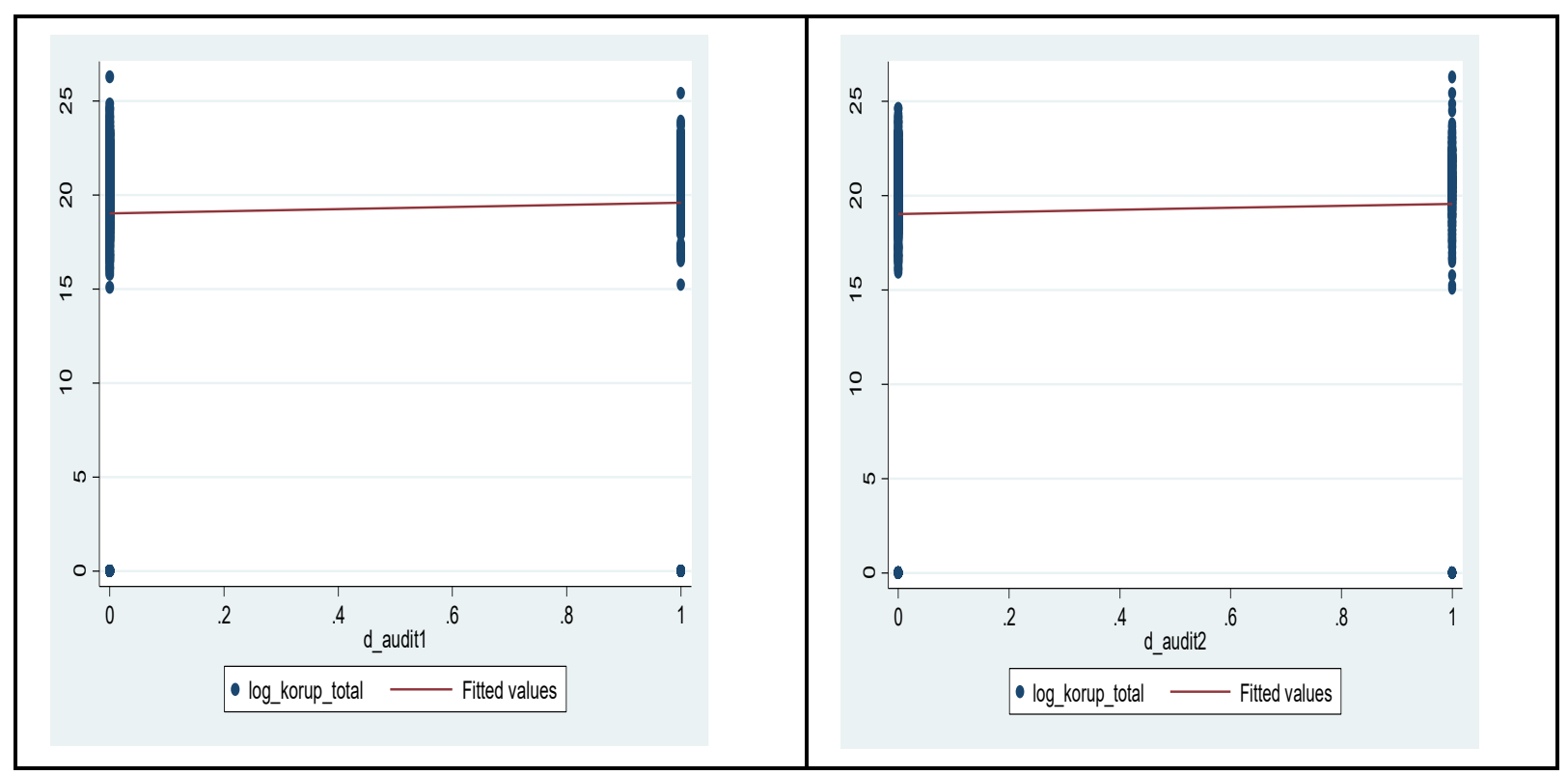




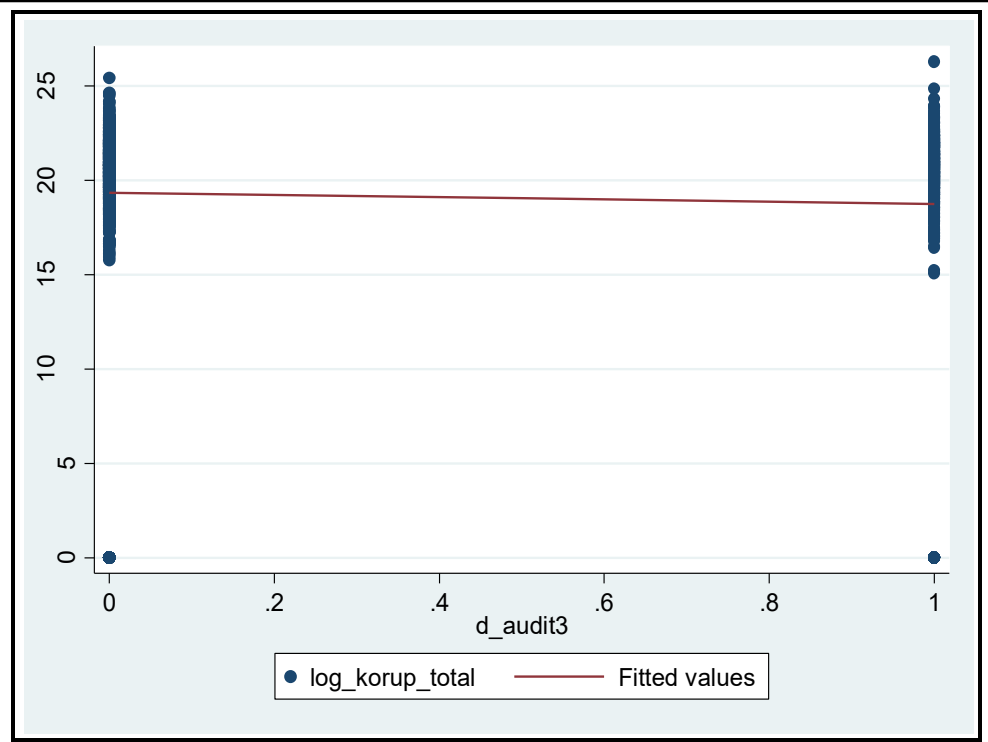

Appendix 2. Hausmann and Correlation Test

Hausman fixed random

\begin{tabular}{|c|c|c|c|c|c|}
\hline & 1 & $\begin{array}{c}\text { (b) } \\
\text { fixed }\end{array}$ & $\begin{array}{l}\text { (B) } \\
\text { random }\end{array}$ & $\begin{array}{c}(b-B) \\
\text { Difference }\end{array}$ & $\begin{array}{c}\left.\operatorname{sgrt}\left(\operatorname{diag}_{(\mathrm{V}} \mathrm{b}^{\mathrm{b}} \mathrm{V}_{-} \mathrm{B}\right)\right) \\
\text { S.E. }\end{array}$ \\
\hline d_audit1 & I & -.6839687 & -.0516018 & -.6323669 & .1484629 \\
\hline d_audit2 & I & -.3627557 & .1984196 & -.5611753 & .1669826 \\
\hline d_audit3 & i & -1.041012 & -.7570981 & -.2839136 & .1343845 \\
\hline in_auditit_k 1 & i & .0120719 & .0805483 & -.0684764 & .0287576 \\
\hline in_audit_k ${ }^{-} \sim 2$ & i & -.0755539 & -.0283652 & -.0471887 & .0278645 \\
\hline in_audit_k ${ }^{-} \sim 3$ & i & -.0491367 & .006393 & -.0555296 & .0273221 \\
\hline $10 \bar{g}$ belañ $j \sim 1$ & I & 1.630188 & 1.118114 & .5120736 & .2939652 \\
\hline d_rasiobm & i & -.5760212 & -.5539019 & -.0221193 & .2110957 \\
\hline log_pend_p a & i & .8748294 & -.1042888 & .9791182 & .4538254 \\
\hline
\end{tabular}

$\mathrm{b}=$ consistent under Ho and Ha; obtained from xtreg $\mathrm{B}=$ inconsistent under $\mathrm{Ha}$, efficient under $\mathrm{Ho}$; obtained from $\mathrm{xtreg}$

Test: Ho: difference in coefficients not systematic

$\begin{array}{rlrl}\operatorname{chi2}(9) & = & \left(b-B_{)}\right)\left[\left(V_{-} b-V_{-} B\right)^{\wedge}(-1)\right](b-B) \\ & = & 230.83 \\ \text { Prob }>\text { chi2 } & = & & 0.0000\end{array}$

corr log_corruptall d_audit d_audit1 d_audit2 d_audit3 log_capex capex_r2 log_incpercap $(\mathrm{ob} \bar{s}=1,999)$

\begin{tabular}{|c|c|c|c|c|c|c|c|c|c|}
\hline log_corrup 1 & । & 1.0000 & & & & & & & \\
\hline d audit & I & 0.2196 & 1.0000 & & & & & & \\
\hline d_āudit1 & i & 0.0375 & 0.0475 & 1.0000 & & & & & \\
\hline d_audit2 & I & 0.0000 & 0.0827 & 0.0139 & 1.0000 & & & & \\
\hline d_audit3 & I & -0.0014 & 0.0329 & 0.0019 & 0.0163 & 1.0000 & & & \\
\hline log'_capex & । & 0.2796 & 0.0938 & 0.0761 & 0.0227 & 0.0280 & 1.0000 & & \\
\hline capex_r2 & i & 0.0544 & -0.0131 & 0.0278 & -0.0007 & -0.0124 & -0.0178 & 1.0000 & \\
\hline log_incper $\sim p$ & I & 0.0283 & 0.0252 & 0.0188 & 0.0065 & 0.0100 & 0.1613 & -0.0407 & 1.0000 \\
\hline
\end{tabular}


JURNAL TATA KELOLA DAN AKUNTABILITAS KEUANGAN NEGARA, Vol. 6, No. 1, 2020: 19-33

Appendix 3. Correlation government expenditure audit and public procurement corruption

\begin{tabular}{|c|c|c|c|c|}
\hline Dependend variable: public procurement cor- & 1 & 2 & 3 & 4 \\
\hline ruption & FE & FE & FE & FE \\
\hline \multirow[t]{2}{*}{ Audit (lag time 1 year) } & $-0.676^{* *}$ & $-0.690^{* *}$ & $-0.684^{* *}$ & $-0.701^{* *}$ \\
\hline & $(0.274)$ & $(0.299)$ & $(0.295)$ & $(0.296)$ \\
\hline \multirow[t]{2}{*}{ Audit (lag time 3 year) } & $-0.514^{*}$ & -0.372 & -0.363 & -0.360 \\
\hline & $(0.275)$ & $(0.299)$ & $(0.297)$ & $(0.294)$ \\
\hline \multirow[t]{2}{*}{ Audit (lag time 3 year) } & $-1.150^{* * *}$ & $-1.078^{* * *}$ & $-1.041^{* * *}$ & $-1.014^{* * *}$ \\
\hline & $(0.296)$ & $(0.313)$ & $(0.311)$ & $(0.306)$ \\
\hline \multirow[t]{2}{*}{ Audit x corruption revealed (lag time 1 year) } & & 0.0172 & 0.0121 & 0.0298 \\
\hline & & $(0.0385)$ & $(0.0388)$ & $(0.0411)$ \\
\hline \multirow[t]{2}{*}{ Audit x corruption revealed (lag time 2 year) } & & -0.0784 & -0.0756 & -0.0617 \\
\hline & & $(0.0765)$ & $(0.0752)$ & $(0.0732)$ \\
\hline \multirow[t]{2}{*}{ Audit x corruption revealed (lag time 3 year) } & & -0.0467 & -0.0491 & -0.0470 \\
\hline & & $(0.0594)$ & $(0.0576)$ & $(0.0584)$ \\
\hline \multirow[t]{2}{*}{ Capital Expenditure } & & & $1.630^{* * *}$ & $1.157^{* *}$ \\
\hline & & & $(0.454)$ & $(0.473)$ \\
\hline \multirow[t]{2}{*}{ Capital Expenditure High Ratio } & & & $-0.576^{*}$ & -0.341 \\
\hline & & & $(0.306)$ & $(0.306)$ \\
\hline \multirow[t]{2}{*}{ GRDP per Capita } & & & 0.875 & 0.644 \\
\hline & & & $(0.722)$ & $(0.757)$ \\
\hline \multirow[t]{2}{*}{ Year=2015 } & & & & 0.540 \\
\hline & & & & $(0.341)$ \\
\hline \multirow[t]{2}{*}{ Year=2016 } & & & & $0.607^{*}$ \\
\hline & & & & $(0.321)$ \\
\hline \multirow[t]{2}{*}{ Year=2017 } & & & & $1.149^{* * *}$ \\
\hline & & & & $(0.314)$ \\
\hline \multirow[t]{2}{*}{ Constant } & $19.83^{* * *}$ & $19.82^{* * *}$ & $-38.13^{* *}$ & -22.34 \\
\hline & $(0.167)$ & $(0.167)$ & $(15.98)$ & $(17.51)$ \\
\hline $\mathrm{N}$ & 2156 & 2156 & 2156 & 2156 \\
\hline r2 & 0.0113 & 0.0125 & 0.0274 & 0.0356 \\
\hline \multicolumn{5}{|l|}{$\operatorname{ar2}$} \\
\hline r2_o & 0.00000494 & 0.0000352 & 0.00783 & 0.0112 \\
\hline
\end{tabular}


Appendix 4. Robustness Check

\begin{tabular}{|c|c|c|c|c|}
\hline $\begin{array}{l}\text { Dependend variable: Corruption in the } \\
\text { public procurement }\end{array}$ & $\begin{array}{c}1 \\
\mathrm{FE}\end{array}$ & $\begin{array}{c}2 \\
\mathrm{FE}\end{array}$ & $\begin{array}{c}3 \\
\mathrm{FE}\end{array}$ & $\begin{array}{c}4 \\
\mathrm{FE}\end{array}$ \\
\hline \multirow[t]{2}{*}{ Audit (lag time 1 year) } & $-0.683^{* *}$ & $-0.690^{* *}$ & $-0.701^{* *}$ & $-0.712^{* *}$ \\
\hline & $(0.273)$ & $(0.298)$ & $(0.297)$ & $(0.297)$ \\
\hline \multirow[t]{2}{*}{ Audit (lag time 2 year) } & $-0.507^{*}$ & -0.369 & -0.371 & -0.364 \\
\hline & $(0.273)$ & $(0.298)$ & $(0.298)$ & $(0.294)$ \\
\hline \multirow[t]{2}{*}{ Audit (lag time 3 year) } & $-1.130^{* * *}$ & $-1.055^{* * *}$ & $-1.042^{* * *}$ & $-1.007^{* * *}$ \\
\hline & $(0.295)$ & $(0.311)$ & $(0.312)$ & $(0.306)$ \\
\hline \multirow{2}{*}{$\begin{array}{l}\text { Audit x corruption revealed (lag time } 1 \\
\text { year) }\end{array}$} & & 0.0121 & 0.0127 & 0.0303 \\
\hline & & $(0.0383)$ & $(0.0382)$ & $(0.0404)$ \\
\hline \multirow{2}{*}{$\begin{array}{l}\text { Audit x corruption revealed (lag time } 2 \\
\text { year) }\end{array}$} & & -0.0769 & -0.0767 & -0.0611 \\
\hline & & $(0.0757)$ & $(0.0759)$ & $(0.0730)$ \\
\hline \multirow{2}{*}{$\begin{array}{l}\text { Audit } x \text { corruption revealed (lag time } 3 \\
\text { year) }\end{array}$} & & -0.0487 & -0.0477 & -0.0464 \\
\hline & & $(0.0581)$ & $(0.0579)$ & $(0.0582)$ \\
\hline \multirow[t]{2}{*}{ GRDP per capita } & & & 0.967 & 0.656 \\
\hline & & & $(0.716)$ & $(0.756)$ \\
\hline \multirow[t]{2}{*}{ Year 2015} & & & & $0.564^{*}$ \\
\hline & & & & $(0.342)$ \\
\hline \multirow[t]{2}{*}{ Year 2016} & & & & $0.643^{* *}$ \\
\hline & & & & $(0.308)$ \\
\hline \multirow[t]{2}{*}{ Year 2017} & & & & $1.224^{* * *}$ \\
\hline & & & & (0.299) \\
\hline \multirow[t]{2}{*}{ Constanta } & $-6.585^{* * *}$ & $-6.586^{* * *}$ & $-23.32^{*}$ & -18.56 \\
\hline & $(0.166)$ & $(0.166)$ & (12.41) & (13.05) \\
\hline $\mathrm{N}$ & 2156 & 2156 & 2156 & 2156 \\
\hline$r 2$ & 0.0111 & 0.0123 & 0.0145 & 0.0252 \\
\hline \multicolumn{5}{|l|}{ ar2 } \\
\hline r2_o & 0.0000616 & 0.0000240 & 0.000134 & 0.00128 \\
\hline
\end{tabular}

Selected and Revised Papers from The International Conference of State Finance and Accountabillity (InCSFA 2019) (Badan Pemeriksa Keuangan Republik Indonesia, by $10^{\text {th }}$ October 2019) after peer-reviewed by Organizing Committee of InCSFA and Peer-reviewers of Jurnal Tata Kelola and Akuntabilitas Keuangan Negara 


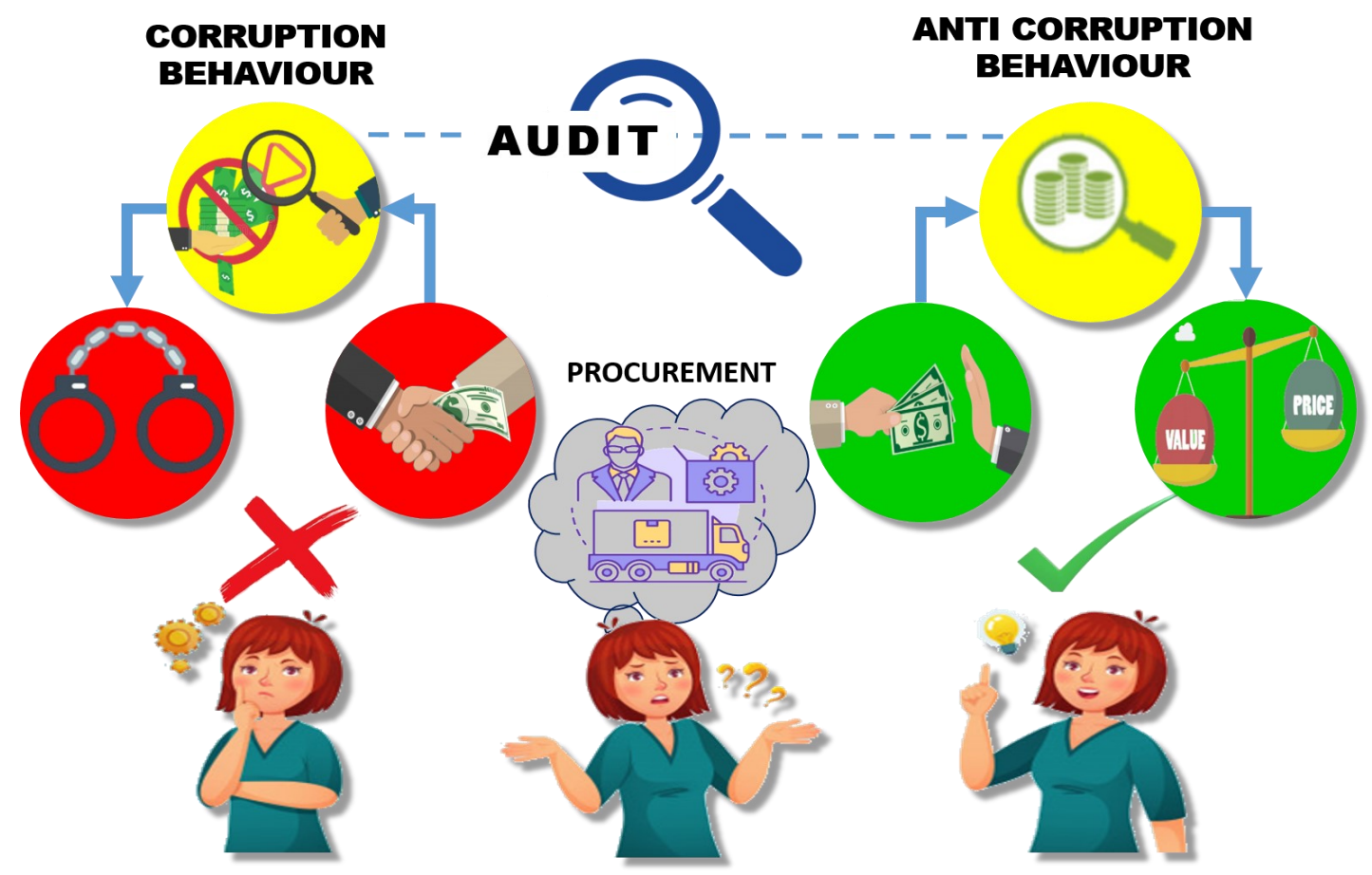

